\title{
FAKTOR-FAKTOR YANG MEMPENGARUHI PERILAKU PEKERJA TERHADAP PENCEGAHAN GANGGUAN PENDENGARAN AKIBAT BISING
}

\author{
Mahmudi $^{*}$, Devita Sari ${ }^{2}$, Rudy Joegijantoro ${ }^{3}$
}

${ }^{1}$ STIKes Widyagama Husada

${ }^{2}$ STIKes Widyagama Husada

${ }^{3}$ STIKes Widyagama Husada

\section{Corresponding author:}

Devita Sari

STIKES Widyagama Husada

Email: devita.sariok@gmail.com

\section{Article Info:}

Dikirim:

Ditinjau:

Diterima:

DOI:

https://doi.org/10.33475/jikmh.v7i2.21

\begin{abstract}
Exposure of noise on long and continuous time can cause Noise Induced Hearing Loss (NIHL). The incident of NIHL worldwide is estimated at 600 million workers who are exposed to noise in the workplace. More than 5\% of the world's population has a hearing loss (328 million adults and 32 million children). The purpose of this study was to determine the factors that influence worker behavior towards the prevention of NIHL in CV. Pakis Indah. The research design used is observational and cross sectional research. The sample in this study had a total of 20 people who were taken referring to the inclusion and exclusion criteria using a total sampling technique. The instrument used in this questionnaire has been tested for validity and reliability. Data analysis used univariate analysis and bivariate analysis with Chi-square test. The results showed that the age category is the most at $\leq 40$ years were 13 people (65\%), the gender affected mostly was male as many as 15 people (75\%), the knowledge level of the respondents was mostly in the unfavourable category, which is 13 people (65\%), and the highest level of education is the junior secondary category is 9 people (45\%). The results of the Chi-square test showed that the factor affecting workers' behavior in the prevention of NIHL is the knowledge level $(p=0.000)$.So it can be concluded that there is an influence between the knowledge level and behavior of workers on the prevention of NIHL at CV. Pakis Indah.
\end{abstract}

Keywords: worker; behavior; prevention; NIHL.

\begin{abstract}
Abstrak
Pajanan kebisingan dalam kurun waktu lama dan secara berkelanjutan dapat menyebabkan gangguan pendengaran akibat bising (GPAB). Di seluruh dunia kejadian GPAB diperkirakan sebesar 600 juta pekerja yang telah terpajan bising di tempat kerja. Gangguan pendengaran pada populasi dunia lebih besar dari 5\% (328 juta jiwa dan 32 juta jiwa anak-anak). Penelitian bertujuan untuk mengetahui faktor-faktor yang mempengaruhi perilaku pekerja terhadap pencegahan GPAB di CV. Pakis Indah. Desain penelitian yang digunakan yaitu penelitian observasional dan cross sectional. Sampel pada penelitian mempunyai jumlah 20 orang yang diambil mengacu pada kriteria inklusi dan ekslusi memakai teknik total sampling. Instrumen yang dipakai dalam kuesioner ini telah dilakukan pengujian validitas dan reliabilitas. Analisis data menggunakan analisis univariat dan analisis bivariat dengan uji Chi-square. Hasil penelitian pada kategori usia paling banyak pada usia $\leq 40$ tahun atau 13 orang $(65 \%)$, jenis kelamin terbanyak pada jenis kelamin laki-laki sejumlah 15 orang $(75 \%)$, tingkat pengetahuan responden paling banyak pada kategori kurang yaitu 13 orang $(65 \%)$, dan tingkat Pendidikan pada kategori SMP sejumlah 9 orang (45\%). Dari hasil uji Chi-square didapatkan faktor yang berpengaruh terhadap perilaku pekerja dalam pencegahan GPAB adalah tingkat pengetahuan $(p=0,000)$. Sehingga disimpulkan bahwa terdapat pengaruh antara tingkat pengetahuan dengan perilaku pekerja terhadap pencegahan gangguan pendengaran akibat bising (GPAB) di CV. Pakis Indah.
\end{abstract}

Kata Kunci: Pekerja; Perilaku; Pencegahan; GPAB. 


\section{PENDAHULUAN}

Permasalahan pajanan kebisingan adalah masalah yang serius karena terdapat \pm 600 juta pekerja di seluruh dunia sudah terkena paparan kebisingan di tempat kerja. Gangguan pendengaran yang dialami pada populasi dunia $\pm 5 \%$ atau 328 juta jiwa orang dewasa dan 32 juta jiwa anak-anak dan remaja). Tingkat kejadian ketulian di Indonesia sebesar 4,6\% (16 juta orang) dan gangguan pendengaran sebesar $16,8 \%$ dari total populasi di Indonesia (Eryani et al., 2017).

Gangguan pendengaran akibat bising (GPAB) atau Noise Induced Hearing Loss (NIHL) merupakan gangguan dengan model sensorineural yang bersumber dari paparan bising dalam dalam jangka waktu yang lama dan cukup keras. Kebisingan yang $>90 \mathrm{~dB}$ (sangat kuat) dapat menyebabkan gangguan pada telinga yang dapat menurunkan kemampuan pendengaran (Jumali et al., 2013). Pekerja yang melakukan pekerjaan di suatu tempat dengan tingkat kebisingan yang tinggi perlu mengetahui pencegahan terhadap kebisingan tersebut. Pengetahuan pekerja dapat dilihat berdasarkan usia, tingkat pendidikan, dan pengalamannya dalam bekerja. Pengetahuan seseorang yang baik akan mendukung perilaku yang lebih baik pula (Desinta et al., 2017).

Berdasarkan hasil studi pendahuluan di CV. Pakis Indah, semua karyawan di CV. Pakis Indah bekerja selama 8 jam kerja dalam 1 minggu. Semua karyawan yang bekerja tidak ada yang menggunakan alat pelindung telinga sebagai upaya pencegahan terhadap paparan kebisingan. Pekerja tidak menggunakan alat pelindung telinga dikarenakan CV. Pakis Indah juga tidak menyediakan sarana dan prasarana pencegahan. Dari hasil wawancara yang telah dilakukan, pekerja rata-rata mengalami keluhan pendengaran. Banyak faktor yang mempengaruhi perilaku pekerja sehingga tidak menerapkan perilaku pekerja terhadap pencegahan terhadap GPAB. Berdasarkan uraian diatas, maka perlu dilakukan penelitian tentang faktor-faktor apa saja yang mempengaruhi perilaku pekerja terhadap pencegahan gangguan pendengaran akibat bising (GPAB) di CV. Pakis Indah.

\section{METODE}

Desain penelitian yang dilakukan adalah analitik observasional dengan pendekatan cross sectional. Populasi dan sampel pada penelitian ini sebanyak 20 orang yang bersumber dari teknik Total Sampling. Variabel independen terdiri dari usia, jenis kelamin, dan tingkat pendidikan pekerja. Sedangkan variabel dependennya yaitu perilaku pekerja terhadap pencegahan GPAB. Penelitian ini dilakukan di CV. Pakis Indah mulai dari Bulan November 2020 Februari 2021. Analisis data menggunakan analisis univariat dan bivariat dengan uji statistik Chi-square. Instrumen yang digunakan adalah kuesioner yang telah diuji validitas dan reliabilitas.

\section{HASIL DAN PEMBAHASAN}

Karakteristik Responden

Tabel 1. Karakteristik Responden

\begin{tabular}{|c|c|c|}
\hline Variabel & $\begin{array}{c}\text { Jumlah } \\
\text { (n) }\end{array}$ & $\begin{array}{c}\text { Persentase } \\
(\%)\end{array}$ \\
\hline \multicolumn{3}{|l|}{ Usia } \\
\hline$>40$ tahun & 7 & 35 \\
\hline$\leq 40$ tahun & 13 & 65 \\
\hline \multicolumn{3}{|l|}{ Jenis Kelamin } \\
\hline Laki-laki & 15 & 75 \\
\hline Perempuan & 5 & 25 \\
\hline \multicolumn{3}{|l|}{ Tingkat } \\
\hline \multicolumn{3}{|l|}{ Pengetahuan } \\
\hline Kurang & 13 & 65 \\
\hline Cukup & 6 & 30 \\
\hline Baik & 1 & 5 \\
\hline \multicolumn{3}{|l|}{ Tingkat } \\
\hline \multicolumn{3}{|l|}{ Pendidikan } \\
\hline $\mathrm{SD}$ & 5 & 25 \\
\hline SMP & 9 & 45 \\
\hline SMA & 5 & 25 \\
\hline Perguruan Tinggi & 1 & 5 \\
\hline \multicolumn{3}{|l|}{ Perilaku Pekerja } \\
\hline Kurang & 14 & 70 \\
\hline Cukup & 6 & 30 \\
\hline Baik & 0 & 0 \\
\hline
\end{tabular}


Pada tabel 1 tentang karakeristik responden diketahui bahwa responden dengan usia $\leq 40$ tahun (13 orang atau 65\%), hampir semua responden dengan jenis kelamin laki-laki sebanyak 15 orang atau $75 \%$, tingkat pengetahuan responden memiliki tingkat pengetahuan kurang sebanyak 13 orang (65\%), tingkat pendidikan responden paling banyak pada tingkatan SMA dengan persentase sebesar 45\% dan Sebagian besar responden memiliki perilaku kurang sebanyak 14 orang dengan persentase $70 \%$.

Tabel 2. Hasil Analisis Bivariat Pengaruh Usia terhadap Perilaku Pekerja dalam Pencegahan GPAB di CV. Pakis Indah

\begin{tabular}{cc}
\hline Variabel & Nilai Signifikan \\
\hline Usia & 0,919 \\
\hline
\end{tabular}

Pada tabel 2 dapat diketahui bahwa bahwa hasil uji Chi-square pengaruh antara usia dengan perilaku pekerja mendapatkan nilai signifikan sebesar 0.919, dimana $\alpha>0.05$ yang menunjukkan bahwa $\mathrm{H} 1$ ditolak, yang artinya tidak ada pengaruh antara usia dengan perilaku pekerja.

Usia merupakan komponen pada faktor predisposisi. Menurut Notoatmodjo (2012), perilaku juga bergantung pada karakteristik atau faktor lain dari pekerja itu sendiri. Salah satu karakteristik dari tenaga kerja adalah faktor usia yang mempengaruhi perilaku pekerja terhadap pencegahan gangguan pendengaran akibat bising (GPAB). Seiring dengan bertambahnya usia seseorang, fisik, tenaga, pemikiran dan mental pasti akan mengalami perubahan tergantung dari jenis pekerjaan yang dilakukannya. Penelitian ini sejalan dengan penelitian Agustina (2015) yang menyatakan bahwa tidak ada pengaruh antara usia dengan perilaku pemakaian alat pelindung diri (Agustina, 2015). Akan tetapi, Hasil penelitian yang telah dilakukan Jannah (2018), tidak sejalan dengan penelitian ini karena pada penelitiannya menyatakan bahwa terdapat hubungan antara usia pekerja dengan kepatuhan pekerja menggunakan APD. Adanya perbedaan hasil penelitian, baik yang sejalan atau yang berbeda dengan penelitian ini tentang pengaruh usia dengan perilaku seseorang dikarenakan semakin tua usia seseorang, maka tingkat pengetahuan dan perilaku seseorang juga semakin menurun, sehingga usia dapat dikatakan sebagai faktor dapat mempengaruhi perilaku seseorang.

Tabel 3. Hasil Analisis Bivariat Pengaruh Jenis Kelamin terhadap Perilaku Pekerja dalam Pencegahan GPAB di CV. Pakis Indah

\begin{tabular}{lc}
\hline \multicolumn{1}{c}{ Variabel } & Nilai Signifikan \\
\hline Jenis Kelamin & 0,573 \\
\hline
\end{tabular}

Pada tabel 3 tentang uji biaviat dapat diketahui bahwa hasil uji Chi-square pengaruh antara jenis kelamin dengan perilaku pekerja pada responden mendapatkan hasil dengan nilai signifikan sebesar 0.573 dimana $\alpha>0.05$, sehingga $\mathrm{H} 1$ ditolak. Jika H1 ditolak, maka dapat diartikan bahwa tidak ada pengaruh antara jenis kelamin dengan perilaku pekerja.

Hasil tersebut sejalan dengan penelitian Apriluana (2016) yang menyatakan bahwa tidak ada pengaruh yang signifikan antara jenis kelamin dengan perilaku penggunaan alat pelindung diri. Hal ini dikarenakan apapun jenis kelaminnya tidak mempengaruhi perilaku pencegahan. Jenis kelamin laki-laki atau perempuan mempunyai kesempatan yang sama untuk melakukan pencegahan atau tidak.

Menurut Green (2005) jenis kelamin termasuk dalam faktor predisposisi yang memberikan kontribusi terhadap perilaku kesehatan. Penelitian yang dilakukan oleh Farihatun dan Mamdy (2016) menunjukkan bahwa jenis kelamin responden 
memiliki hubungan terhadap perilaku pencegahan terhadap penyakit.

Tabel 4. Hasil Analisis Bivariat Pengaruh Tingkat Pengetahuan terhadap Perilaku Pekerja dalam Pencegahan GPAB di CV. Pakis Indah

\begin{tabular}{cc}
\hline Variabel & Nilai Signifikan \\
\hline Tingkat Pengetahuan & 0,000 \\
\hline
\end{tabular}

Berdasarkan pada tabel 4 diperoleh hasil bahwa pengaruh antara tingkat pengetahuan dengan perilaku pekerja pada responden mendapatkan hasil dengan nilai signifikan sebesar 0.000 dimana $\alpha<0.05$, sehingga Ho ditolak dan H1 diterima. Sehingga dapat diartikan bahwa ada pengaruh antara tingkat pengetahuan dengan perilaku pekerja.

Hasil penelitian selaras dengan penelitian Edigan (2019) yaitu terdapat hubungan yang signifikan antara tingkat pengetahuan pekerja dengan perilaku penggunaan alat pelindung diri (APD) $(\mathrm{p}=0,003)$. Hal ini dapat terjadi karena pengetahuan tentang informasi adalah pondasi awal terjadinya perilaku. Pengetahuan yang minor tentang APD menyebabkan pekerja tidak memahami pola perilaku dalam penggunaan APD, sehingga dalam melakukan pekerjaannya lebih rentan memiliki dampak yang lebih besar terjadi gangguan pendengaran ataupun penyakit akibat kerja daripada pekerja yang memiliki perilaku baik terhadap penggunaan APD (Edigan et al, 2019).

Responden yang memiliki pengetahuan yang baik, akan berperilaku positif terhadap pencegahan GPAB. Begitu pula pada responden yang memiliki pengetahuan kurang, akan memiliki perilaku negatif terhadap pencegahan GPAB. Akan tetapi, peningkatan pengetahuan tidak selalu menyebabkan perubahan perilaku, namun masih terdapat hubungan positif antara kedua variabel ini yang telah diperlihatkan dalam sejumlah penelitian yang dilakukan. Pengetahuan tertentu tentang perilaku pekerja terhadap GPAB pencegahan sangat penting sebelum seseorang mengalami GPAB, tetapi perilaku pencegahan yang diharapkan tidak akan terjadi apabila pekerja tidak mendapat kesadaran yang cukup kuat untuk berperilaku atas dasar pengetahuan yang dimilikinya.

Pengetahuan sangat erat hubungannya dengan pendidikan, semakin besar pengetahuan dan wawasan yang dimiliki, maka dapat mencerminkan bahwa seseorang itu mempunyai pendidikan yang tinggi. Akan tetapi belum tentu seseorang dengan pendidikan yang rendah akan berwawasan dan berpengetahuan rendah juga, karena peningkatan pengetahuan seseorang dapat diperoleh pada pendidikan formal dan non formal (Apriluana et al, 2016). Pengetahuan responden tentang alat pelindung diri dan bahaya dari kebisingan berpengaruh terhadap perilaku pada saat bekerja, atau dengan kata lain bahwa pengetahuan merupakan faktor yang sangat penting dalam membentuk tindakan atau perilaku seseorang.

\section{Tabel 5. Hasil Analisis Bivariat Pengaruh Tingkat}

Pendidikan terhadap Perilaku Pekerja dalam Pencegahan GPAB di CV. Pakis Indah

\begin{tabular}{cc} 
Variabel & Nilai Signifikan \\
\hline Tingkat Pendidikan & 0,381
\end{tabular}

Pada tabel 5 dapat diketahui bahwa hasil uji Chisquare pengaruh antara tingkat pendidikan dengan perilaku pekerja pada responden mendapatkan hasil dengan nilai signifikan sebesar 0.381 dimana $\alpha>$ 0.05, sehingga $\mathrm{H} 1$ ditolak. Jika H1 ditolak diartikan bahwa tidak ada pengaruh antara tingkat pendidikan dengan perilaku pekerja.

Tingkat pendidikan merupakan salah satu komponen yang termasuk dalam faktor predisposisi. Luasnya pengetahuan seseorang ditentukan oleh pendidikan 
seseorang, dimana seseorang yang memiliki tingkat pendidikan rendah akan sulit menerima sesuatu hal yang baru. Menurut Notoatmodjo (2012), pendidikan diartikan sebagai masing-masing dari pengaruh, usaha, perlindungan dan bantuan yang akan ditujukan kepada anak didik yang berproses menjadi dewasa. Hal tersebut secara tidak langsung akan memiliki pengaruh terhadap perilaku dari pekerja.

Semakin tinggi pendidikan seseorang, maka semakin besar pula kemungkinan seseorang untuk memperoleh informasi dan semakin besar juga kemungkinan tenaga kerja dapat bekerja dan melaksanakan pekerjaannya dengan baik. Semakin banyak informasi yang didapatkan, maka akan semakin besar pula pengetahuan yang dimiliki, sehingga dapat berpengaruh terhadap seseorang dalam berperilaku. Meskipun berbeda dengan teori yang dikemukakan oleh Notoatmodjo (2012), penelitian ini sejalan dengan penelitian yang dilakukan oleh Andriyanto (2017) di PT. Petrokimia Gresik yang menyatakan tidak terdapat hubungan antara tingkat pendidikan dengan perilaku penggunaan alat pelindung diri ( $\mathrm{p}$-value $=1,000)$.

Pendidikan seseorang dapat menyediakan dan menambah informasi bagi pekerja tentang pencegahan gangguan pendengaran akibat bising (GPAB). Seseorang akan mampu melakukan pencegahan apabila memiliki pendidikan yang tinggi serta diimbangi dengan pengetahuan yang baik. Pendidikan yang tinggi memang belum menjamin seseorang untuk dapat berperilaku baik, akan tetapi pendidikan dapat menjadi salah satu faktor pendukung dalam terciptanya perilaku yang baik, khususnya dalam menerapkan pencegahan GPAB.

\section{KESIMPULAN}

Karakteristik responden dengan kategori usia tertinggi pada umur $\leq 40$ tahun sejumlah 13 responden dan kategori jenis kelamin tertinggi pada responden dengan jenis kelamin laki-laki sejumlah 15 responden, dan untuk kategori tingkat pendidikan paling banyak terdapat pada tingkatan SMP dengan jumlah 9 responden serta tingkat pengetahuan tertinggi terdapat pada pengetahuan dengan kategori kurang dengan jumlah 13 responden. Berdasarkan hasil analisis bivariat menggunakan Chi-square, tidak terdapat pengaruh antara usia, jenis kelamin dan tingkat pendidikan dengan perilaku pekerja terhadap pencegahan gangguan pendengaran akibat bising (GPAB) di CV. Pakis Indah. Sedangkan untuk variabel tingkat pengetahuan berpengaruh terhadap perilaku pekerja dalam pencegahan gangguan pendengaran akibat bising (GPAB) di CV. Pakis Indah.

\section{UCAPAN TERIMA KASIH}

Ucapan terima kasih kami sampaikan kepada semua pihak yang turut mendukung dan berkontribusi dalam penelitian ini, sehingga penelitian ini dapat terselesaikan dengan baik dan tepat waktu.

\section{DAFTAR RUJUKAN}

Agustina, D. E. (2015). Perilaku Pemakaian Alat Pelindung Diri (APD) (Studi di Bagian Coal and Ash Handling PT. PJB UBJ O\&M PLTU Paiton). Artikel Penelitian. Jember: Universitas Jember.

Andriyanto, M. R. (2017). Hubungan Predisposing Factor Dengan Perilaku Penggunaan APD. The Indonesian Journal of Occupational Safety and Health, 6 (1), 37-47.

Apriluana, G., Khairiyati, L \& Setyanigrum, R. (2016). Hubungan Antara Usia, Jenis Kelamin, 
Lama Kerja, Pengetahuan, Sikap Dan Ketersediaan Alat Pelindung Diri (APD) Dengan Perilaku Penggunaan Apd Pada Tenaga Kesehatan. Jurnal Publikasi Kesehatan Masyarakat Indonesia, 3(3), 82-87.

Desinta, I., Andarani, P., \& Budiawan, W. (2017). Analisis faktor risiko gangguan pendengaran dan estimasi excess risk gangguan pendengaran akibat paparan kebisingan pada personel kabin masinis DAOP IV Semarang. Jurnal Teknik Lingkungan, 1-11.

Edigan, F., Sari, L. R. P., \& Amalia, R. (2019). Hubungan Antara Perilaku Keselamatan Kerja Terhadap Pengguna an Alat Pelindung Diri (APD) Pada Karyawan PT Surya Agrolika Reksa di Sei . Basau. Jurnal Saintis. 19 (2), hal: 61-70.

Eryani, Y. M., Wibowo, C. A., \& Saftarina, F. (2017). Faktor Risiko Terjadinya Gangguan Pendengaran Akibat Bising. Medula, 7(4), 112117.

Farihatun, A., \& Mamdy, Z. (2016). Faktor-Faktor yang Berhubungan Dengan Perilaku Pencegahan Penyakit Malaria Pada Masyarakat di Desa Karyamukti Kecamatan Cibalong Kabupaten Garut Provinsi Jawa Barat. Jurnal Kesehatan Bakti Tunas Husada, 15 (1), 109121.

Green, L. (2005). Health Program Planning an A Education and Eecological Approach Fourth Edition. California : McGraw-Hill Companies. Jannah, M., \& Handari, S. R. T. (2018). Hubungan Antara Karakteristik, Kenyamanan, Dan Dukungan Sosial Dengan Perilaku Penggunaan Alat Pelindung Diri (APD) Pada Petani Pengguna Pestisida Di Desa "X” Tahun 2018. Environmental Occupational Health and Safety Journal, 1 (1), 17-28.
Jumali, Sumadi, Andriani, S., Subhi, M., Suprijanto, D., Handayani W. D., Chodir, A., Noviarmi, F. S. I \& Indahwati, L. (2013). Prevalensi dan Faktor Risiko Tuli Akibat Bising pada Operator Mesin Kapal Feri. Jurnal Kesehatan Masyarakat Nasional, 7 (12), 545-550.

Notoatmodjo, S. (2012). Pendidikan dan Perilaku Kesehatan. Jakarta: Rineka Cipta.

Cite this article as: Mahmudi., Sari, D., Joegijantoro, R. (2021). Faktor-faktor Yang Mempengaruhi Perilaku Pekerja Terhadap Pencegahan Gangguan Pendengaran Akibat Bising. Jurnal Ilmiah Media Husada. 10(2), 109-114.

https://doi.org/10.33475/jikmh.v7i2.21 